\title{
Pulmonary agenesis as part of the VACTERL sequence
}

\author{
S KNOWLES, $*$ R M THOMAS, $† \mathrm{R}$ H LINDENBAUM, $\$ \mathrm{~J}$ W KEELING,\$ AND R M WINTER $\dagger$ \\ "Queen Victoria Hospital, South Australia; $†$ Northwick Park Hospital, Harrow; $\ddagger$ Churchill Hospital, \\ Oxford; and \$John Radcliffe Hospital, Oxford
}

SUMMARY Pulmonary agenesis is an uncommon anomaly that has been reported in isolation and in association with other congenital defects. Such defects include oesophageal atresia, cardiac malformation, horseshoe kidney, and anal atresia. Over a period of three years we have seen five neonates or fetuses with unilateral agenesis of the lung. All the cases had three or more anomalies seen in the VACTERL sequence in addition to the pulmonary atresia. None had a tracheo-oesophageal fistula. None were the products of consanguineous marriages. There had been no recurrence of this range of defects in any of the familes at the time of writing. We suggest that pulmonary agenesis may occur as an alternative to tracheo-oesophageal fistula in the VACTERL sequence.

VACTERL is an acronym widely applied to a group of Vertebral, Anal, and Cardiac defects, TracheoEsophageal fistula, and Renal and Limb defects occurring in a non-random association.' Other acronyms have included VATER. ${ }^{2}$ VACTEL, ARTICLE, TREACLE, and LEATHER, and in the last two the second E refers to 'Etcetera'. ${ }^{3}$ Though the existence of an association is not in doubt, the broadest form of the sequence merges with caudal regression and complexes associated with choanal atresia (CHARGE) and Mullerian duct aplasia (MURCS). It may also represent the phenotype of several chromosome anomalies includ- ing trisomy 13 and $13 \mathrm{q}-$. The designation 'syndrome' does not, therefore, seem appropriate.

Czeizel and Ludanyi, ${ }^{+}$in a comprehensive review, divided their cases into those with 'true' VACTERL in which three or more features were found alone, and 'mixed' VACTERL, in which there were other congenital anomalies. They also divided the features of the association into 'close' and 'broad' definitions (table 1). Using these stringent definitions true VACTERL becomes a more specific entity, which is reasonably well separated from similar phenotypes. The precise developmental mechanism has not been identified but all the defects can be explained by an

Table 1 Definitions of VACTERL ${ }^{+}$

\begin{tabular}{|c|c|c|}
\hline Type of anomaly & Close definition & Broad definition \\
\hline Vertebral anomalies & $\begin{array}{l}\text { Absence of vertebra fusion } \\
\text { Hemivertebra } \\
\text { Spina bifida occulta }\end{array}$ & $\begin{array}{l}\text { Other vertebral anomalies or } \\
\text { rib absence or fusion }\end{array}$ \\
\hline Anal atresia & $\begin{array}{l}\text { With or without rectovaginal or perincal fistula } \\
\text { including anal stenosis }\end{array}$ & $\begin{array}{l}\text { Atresia with other } \\
\text { gastrointestinal anomalies }\end{array}$ \\
\hline Cardiac defects & $\begin{array}{l}\text { Ventricular septal defect } \\
\text { Atrial septal defect } \\
\text { Tetralogy of Fallot }\end{array}$ & $\begin{array}{l}\text { Other cardiovascular } \\
\text { anomalies }\end{array}$ \\
\hline Tracheo-Esophageal fistula & $\begin{array}{l}\text { Includes atresia without fistula, and fistula without } \\
\text { atresia }\end{array}$ & Oesophageal stenosis \\
\hline Renal anomalies & Unilateral or bilateral renal agenesis or dysplasia & $\begin{array}{l}\text { Accessory, double or fused } \\
\text { kidneys. and others }\end{array}$ \\
\hline Limb anomalies & $\begin{array}{l}\text { Preaxial reduction (radial or ulnar) } \\
\text { Preaxial polydactyly }\end{array}$ & $\begin{array}{l}\text { Other reductions } \\
\text { Other polydactylies }\end{array}$ \\
\hline
\end{tabular}


insult occurring during early embryogenesis. The radial defects have been explained as vascular abnormalities - for example, absence of the radial artery. 5

Because the bifurcation of the tracheal primordium and the subsequent initiation of lung development occur within the period encompassed by the VACTERL sequence, it would not be surprising to find bilateral or unilateral pulmonary agenesis as part of the same range of defects.

\section{Case reports}

\section{CASE 1}

A female infant was born to a 26 year old primigravida after a prolonged labour requiring rotation with Kielland's forceps. The pregnancy had been uneventful except that the mother had had wisdom teeth removed during the first trimester. This had required heavy analgesia, which made her extremely ill; the identity of the drug was not known. At delivery the infant weighed $3140 \mathrm{~g}$ and had skeletal abnormalities. The right lung was thought to be collapsed and the infant died despite intensive care. At necropsy there was right pulmonary agenesis as well as other anomalies (table 2).

\section{CASE 2}

A female infant died after three days with poor respiratory function, radial aplasia, aplasia of the left pectoralis major, and a 'hypoplastic' left lung (fig 1). She had been delivered after spontaneous premature labour at 36 weeks' gestation. Severe intrauterine growth retardation had been noted at
18 weeks. At necropsy left pulmonary agenesis together with skeletal, urogenital, and anal anomalies were found (table 2). Two previous pregnancies had been uneventful and had resulted in babies born alive.

CASE 3

A stillborn male infant with multiple anomalies was delivered electively at 31 weeks' gestation after ultrasound investigation of the 23 year old primigravida mother had shown oligohydramnios and renal agenesis. (table 2).

\section{CASE 4}

The mother of this infant was a 29 year old woman with two live children. Spontaneous onset of labour was followed by emergency lower segment

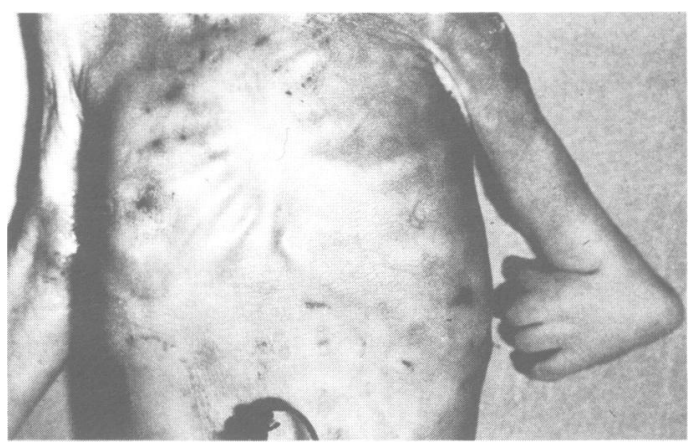

Fig 1 Absence of pectoral muscles, shortening of left arm, and reduction anomalies of forearm and hand (case 2).

Table 2 VACTERL anomalies in this series; broad features in parentheses

\begin{tabular}{|c|c|c|c|c|c|}
\hline Anomaly & Case 1 & Case 2 & Case 3 & Case 4 & Case 5 \\
\hline Vertebral & No (13 ribs) & Cervical hemivertebrac & No $x$-ray & Cervical hemivertebrac & $\begin{array}{l}\text { Lumbosacral and } \\
\text { thoracic hemivertebrace }\end{array}$ \\
\hline Anal & & No & Anal atresia & Anal atresia & Anal atresia \\
\hline Cardiac & Atrial septal defect & No & $\begin{array}{l}\text { Atrial and ventricular septal } \\
\text { defects }\end{array}$ & $\begin{array}{l}\text { Atrial and ventricular septal } \\
\text { defects (Aortic stenosis) }\end{array}$ & $\begin{array}{l}\text { Atrial and ventricular } \\
\text { septal defects }\end{array}$ \\
\hline T-E fistula & (Agenesis right lung) & (Agenesis left lung) & (Agenesis right lung) & (Agenesis left lung) & (Agenesis left lung) \\
\hline Renal & No (Genital anomalies) & No & Bilateral renal dysplasia & No (Horseshoe kidney) & $\begin{array}{l}\text { No (Horseshoe kidney } \\
\text { and genital anomalies) }\end{array}$ \\
\hline Limb & $\begin{array}{l}\text { Bilateral radial aplasia and } \\
\text { absent right thumb }\end{array}$ & $\begin{array}{l}\text { Left radial aplasia, thumb } \\
\text { hypoplasia. and absent } \\
\text { pectorals }\end{array}$ & No $x$-ray & $\begin{array}{l}\text { Bilateral radial aplasia and } \\
\text { proximal humoral aplasia: } \\
\text { absent digits }\end{array}$ & $\begin{array}{l}\text { Left radial aplasia and } \\
\text { absent digits: left } \\
\text { femoral hypoplasia }\end{array}$ \\
\hline $\begin{array}{l}\text { Total No of } \\
\text { close } \\
\text { anomalies }\end{array}$ & 2 & 2 & 3 & 4 & 4 \\
\hline $\begin{array}{l}\text { Total No of } \\
\text { close and } \\
\text { broad } \\
\text { anomalies }\end{array}$ & (5) & (.3) & (4) & (6) & (6) \\
\hline $\begin{array}{l}\text { Total No of } \\
\text { close } \\
\text { anomalies } \\
\text { if lung } \\
\text { agenesis is } \\
\text { included }\end{array}$ & 3 & 3 & 4 & 5 & 5 \\
\hline
\end{tabular}


caesarean section for fetal distress. A malformed female infant was delivered and the Apgar scores were poor (fig 2). Medical support was discontinued after two hours. The abnormalities found at necropsy are listed in table 2 .

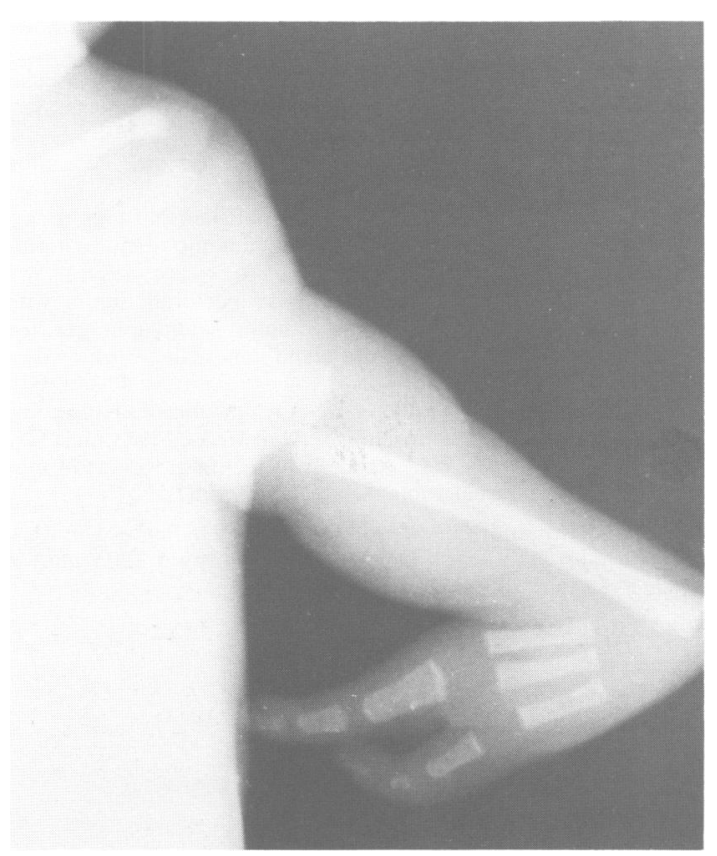

Fig $2 X$-ray showing radial aplasia, absent thumb, and macrosyndactyly (case 4).

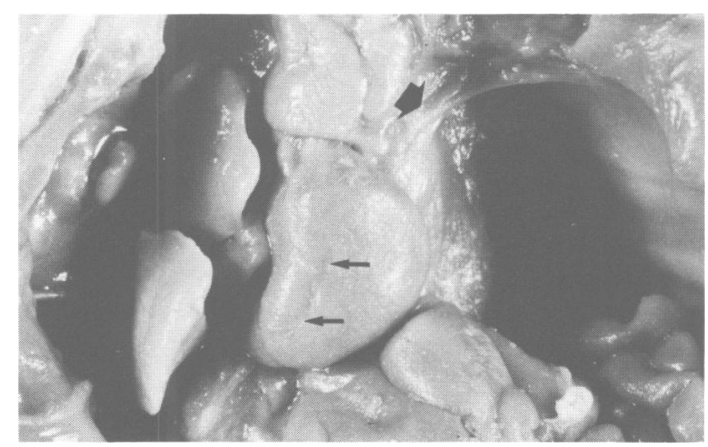

Fig 3 Thoracic contents showing absence of left lung and hemidiaphragm, persistent left superior vena cava (broad arrow) and abnormal cardiac outline with hypoplastic right ventricle. Small arrows indicate anterior descending coronary artery. Loops of intestine protrude into left hemithorax, and right lung is relatively well developed (case 5).
CASE 5

A fetus was referred for histological examination as a missed and macerated abortion. In addition to the anomalies listed in table 2, examination showed a sacral skin tag, a hypoplastic left lower limb, a large left diaphragmatic hernia, 13 pairs of ribs, and a persistent left superior vena cava (fig 3). The gestational age was estimated at 14-15 weeks at the time of death, no cause for which was found.

\section{Discussion}

Pulmonary agenesis has been classified morphologically by the extent to which bronchopulmonary tissue is absent. Earlier classifications were modified by Spencer" ${ }^{\text {" }}$ who divided pulmonary agenesis into: (i) bilateral complete agenesis; (ii) unilateral agenesis with (a) complete absence of bronchi, alveolar tissue, and blood supply, or (b) rudimentary bronchus present but not invested by pulmonary tissue, or (c) poorly developed main bronchus with fleshy mass and poorly organised parenchyma; and (iii) lobar agenesis or lesser forms of congenital anomaly.

Variation in lobation or segmentation in the human lungs is extremely common, and usually of practical importance only to those surgeons who operate on the intrathoracic organs. The complete absence of a lung together with its bronchus is, on the other hand, sufficiently rare to excite considerable interest. The defect commonly occurs in association with other congenital anomalies. Schechter reviewed published reports on the "congenital subtractive bronchopneumonic malformations'. ${ }^{7}$ In 114 cases of complete absence of one or both lungs, other anomalies were detected in the skeleton $(n=30)$, the great vessels $(n=27)$, the cardiac anatomy $(n=26)$, the urogenital system $(n=15)$, the upper respiratory tract $(n=13)$, the face and cranial nerves $(n=13)$, the lower intestinal tract $(n=8)$, and the oesophagus $(n=7)$.

The absence of one lung in association with preaxial reduction anomalies of the upper limb was first described in 1974 as an extreme expression of Poland's syndrome. ${ }^{8}$ In this case the ipsilateral diaphragm was also absent, and there were multiple rib anomalies but no defects of the heart or anus. A further report described triphalangeal thumb, rib anomalies, and a transient cardiac murmur in association with left pulmonary agenesis. ${ }^{9}$ A more recent report of four cases from Saudi Arabia described cases of unilateral lobar or lung aplasia associated with other anomalies. ${ }^{10}$ Three had preaxial upper limb anomalies including triphalangeal thumb, duplicated thumb, and posteriorly placed and contracted thumb. Other individual defects 
included rib fusion, spina bifida, and flexion contractures. All four cases had atrial septal defects, and all four were the products of consanguineous marriages.

All our cases come into Spencer's category (iia). having no evidence of rudimentary bronchi though case 4 had an area of dysplastic right lung parenchyma that could conceivably represent an intrapulmonary sequestrated remnant of the left lung. On histological examination the area resembled cystic adenomatoid malformation and, because there was no evidence of a left main bronchus, the latter explanation therefore appears more probable. Table 2 shows that all five cases had several features of the VACTERL sequence and, if tracheo-oesophageal fistula is replaced by pulmonary agenesis, all can be defined as having the 'close' VACTERL sequence. Over the period that these cases presented we saw no other cases of pulmonary aplasia. We suggest therefore that there is a genuine association between pulmonary agenesis and the other features of the VACTERL sequence, and that the risk of recurrence in subsequent pregnancies is likely to be low.

We thank Professor EO Revnolds. Drs Liberman and Wilkinson. and $\mathrm{Mr}$ HJ I lughes, for permission to publish details of their cases.

\section{References}

1 Kaufman RL. Birth defects and oral contraceptives. Lancet 1973;i: 1396

2 Quan L. Smith DW. The VATER association: Vertebral defects. Anal atresia T-E fistula with esophageal atresia, Radial and Renal dysplasia. A spectrum of associated defects. J Pediatr 1973;82:104-7.

3 Landing BH. Syndromes of congenital heart disease with traceobronchial anomalics. AJR 1975;123:679-86.

4 Czcizel A. Ludanyi I. VACTERL-Association. Acta Morphol Hung 1984;32:75-96

- Hoyme HE. VanAllen MI, Lyon Jones K. The vascular pathogenesis of some sporadically occurring limb defects. Sem Perinatol 1983:7:299-3()6.

"Speneer H. Pathology of the lung. 3rd ed. Oxford: Pergamon Press, 1977:71-114.

${ }^{7}$ Schechter DC. Congenital absence or deficiency of lung tissue. The congenital subtractive bronchopncumonic malformations. Ann Thorac Surg 1968:6:286-313.

$\therefore$ Frias JL. Felman AH. Absence of the pectoralis major with ipsilateral aplasia of the radius, thumb, hemidiaphragm and lung: an extreme expression of Poland's anomaly? Birth Defects 1974:10:55-9.

"Manouvrier S. Aplasia pulmonaire et triphalange du pouce: une nouvelle association malformative? L.arc Medical 1983:iii:373-5.

11) Mardini MK. Nyhan WL. Agenesis of the lung. Report of four patients with unusual anomalics. Chest 1985:87:522-7.

Correspondence and requests for reprints to Dr Simon Knowles. Staff Specialist Pathologist. Queen Victoria Hospital. 160) Fullerton Road. Rose Park. South Australia 5067.

Accepted 11 November 1987 